\title{
Pathology awareness in patients and patient's relatives applying to a pathology laboratory
}

Siddika Findik, MD, PhD, Fatma G. Cihan, $M D$, PhD

\begin{abstract}

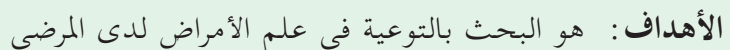

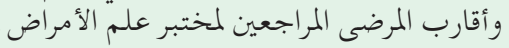

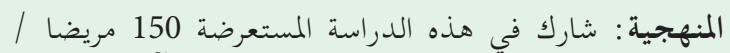

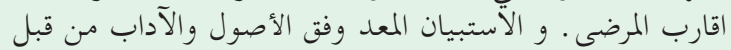

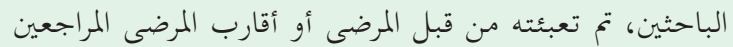

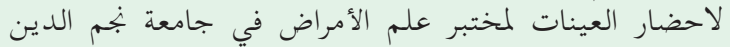
اربكان، قونيا، تركيا في مايو 2018م. لإختر

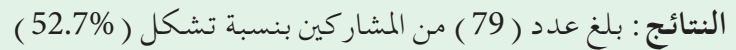

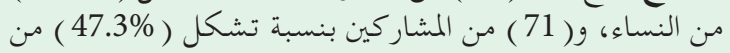

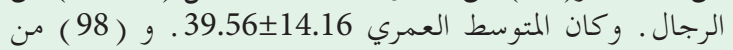

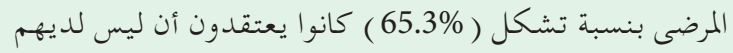

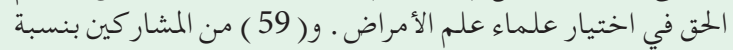

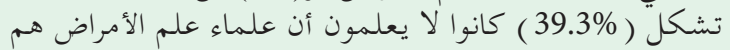

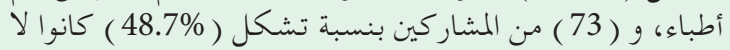

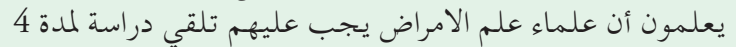

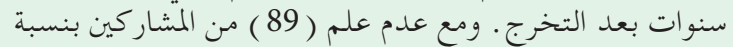

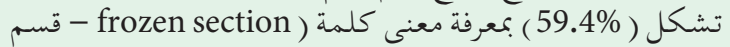

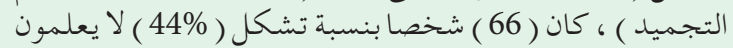

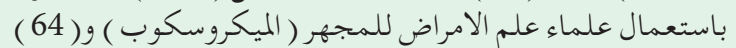

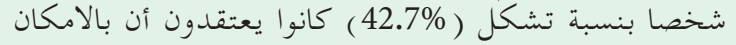

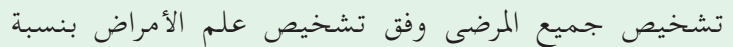

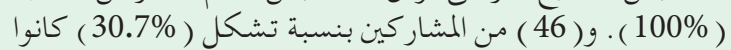

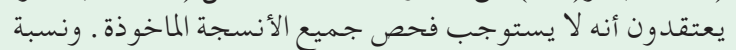

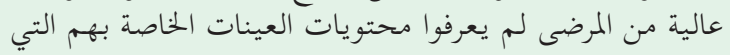

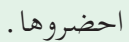

الحلاصة : تم الكشف أن المرضى/أقارب المرضى ليس لديهم

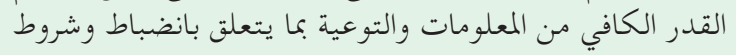

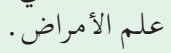

Objectives: To investigate pathology awareness in patients applying to a pathology laboratory.

Method: This cross-sectional study included 150 patients and patients' relatives. A questionnaire, prepared by the researchers according to the literature, was administered at the Pathology Laboratory, Necmettin Erbakan University, Konya, Turkey on May 2018.

Results: Of the participants, 79 (52.7\%) were female and $71(47.3 \%)$ were male. The mean age was $39.56 \pm 14.16$ years old. Ninety-eight $(65.3 \%)$ of them thought that patients do not have right to choose their pathologist. Of the participants, 24 (16\%) did not know that the medical school had to be completed in order to become a pathologist and $73(48.7 \%)$ of them did not know that 4 years postgraduate training was required. Fifty-nine (39.3\%) of the participants did not know the pathologists were a medical doctor. While 89 participants $(59.4 \%)$ had no idea what "frozen section" means, 66 people $(44 \%)$ did not know that the pathologist uses microscope and $64(42.7 \%)$ of them thought that all diseases could be diagnosed $100 \%$ by pathological examination. Forty-six (30.7\%) of the participants thought that all specimens are not needed to be examined.

Conclusion: The knowledge and awareness of the participants about the pathology discipline came out to be inadequate.

\section{Saudi Med J 2019; Vol. 40 (11): 1150-1157} doi: 10.15537/smj.2019.11.24631

From the Department of Pathology (Findik) and Department of Family Medicine (Cihan), Meram Medical School,Necmettin Erbakan University Konya, Turkey.

Received 11th July 2019. Accepted 9th October 2019.

Address correspondence and reprint request to: Dr. Fatma G. Cihan, Department of Family Medicine, Meram Medical School, Necmettin Erbakan University, Konya,Turkey. E-mail: goksincihan@yahoo.com ORCID ID: https://orcid.org/0000-0001-7393-6860 
P athology is a medical specialty that determines the nature and cause of diseases by examining body tissues and fluids. The results of pathologic investigations assist doctors in diagnosing and treating diseases. In modern medicine, pathological examination is indispensable for the definitive diagnosis of many diseases. It is essential for the diagnosis of tumors, for example. In this sense, pathology forms the basis of medicine. ${ }^{1-3}$ Approximately $70 \%$ of important medical decisions made by physicians are based on the results of pathology and laboratory medicine testing. The discipline of pathology is pursued by specialists working in laboratories who are, in spite of being highly educated and having superior skills, not often in the limelight. The discipline is not well-recognized by the public or even by other medical doctors working in clinical branches concerned with working principles. ${ }^{3,4}$ Other members of the management team often overshadow pathologists, even though the latter make the ultimate determination of the nature of a disease and so dictate the course of therapy for an individual patient. Patients often do not understand the role of pathologists in their care, and do not realize that inaccurate interpretation of pathology samples and test results may lead to inappropriate treatment. ${ }^{2-5}$ The issue of pathology only becomes "real" when a patient becomes aware of a mistake in the diagnosis of their disease, or there is a significant discrepancy between the clinical presentation and the pathologic diagnosis. ${ }^{2-5}$ Although it provides vital services to health care systems, it is not appreciated in Turkey or indeed throughout the world because many processes are carried out in the background. Many countries, for example Australia, are making efforts to promote pathology awareness through public information campaigns. ${ }^{6-10}$

In Turkey, patients who visit a pathology laboratory usually do this for anatomical pathology testing (biopsies and other surgical specimens). Pathology materials (such as trucate, punch, endoscopic biopsies and cytological specimens) taken from patients in the outpatient clinics are delivered to pathology laboratory by patients or patients relatives. Samples collected during surgery are mostly delivered to the pathology laboratory by hospital staff in Turkey. There is no requirement to send materials directly from the operating room to the pathology laboratory for accreditation in Turkey. ${ }^{3,11}$

Disclosure. Authors have no conflict of interests, and the work was not supported or funded by any drug company.
All tissue specimens are examined both grossly and microscopically. Sometimes the examination can be very detailed (for example a malignant tumor). The final pathology report with diagnoses is issued by pathologists and is stored in the documentation records of the hospital. As routine, the patient gets a copy of the pathology report. If the diagnosis is uncertain, the hospital pathologist may consult another pathologist in the same or different center. However, if the patient or the patient's doctor has concerns about the pathologist's diagnosis, either may request that these materials to be sent to a different pathologist at another hospital. The new consultant pathologist will issue a report and then send the slides and blocks back to the original pathology laboratory for safekeeping. All of the microscope slides, and the paraffin blocks normally belong to the hospital pathology laboratory, which stores the slides and paraffin blocks for many years; any remaining tissue removed during the operation that is not needed for rendering a diagnosis can be stored for a shorter period and then will be discarded. Each laboratory has storage policies appropriate to their own circumstances in Turkey. ${ }^{3,11}$

Health literacy is the capacity to acquire, interpret, and understand basic health information and services in a way that protects and improves individual health. ${ }^{12,13}$ People applying for health services should be able to make informed decisions about their health problems and the service provided. ${ }^{14}$ Health literacy is associated with general literacy. ${ }^{15}$ The education system of the country and cultural and social factors together with individual beliefs about health potentially affect health literacy. ${ }^{16}$

A survey about public awareness of pathology has not been undertaken before. This study is intended to evaluate the awareness of patients and their relatives about the principles of the discipline of pathology and the pathology laboratory.

Methods. This cross sectional study was approved by the ethical board of the Necmettin Erbakan University (2018/1342) and conducted according to the ethical principles of Helsinki Declaration.

The study group consisted of patients and patients' relatives who applied to a pathology laboratory. A literature review with words "pathology, biopsy, health literacy, knowledge, awareness" in PubMed, Clinical Key and Google Scholar was made. In addition to the sociodemographic properties of the participants, a questionnaire consisting of 20 items (14 true or false questions and 6 multiple-choice questions) about pathology and pathology laboratory procedures, prepared by the researchers using national and 
international documents ${ }^{2-6}$ was administered. The survey was conducted at the pathology laboratory of Necmettin Erbakan University, Konya, Turkey, from May 1st to May 31st, 2018, when patients or their relatives brought samples to the laboratory. All applicants $(\mathrm{n}=328)$ were invited to participate and volunteering ones $(n=168)$ were included. People who were not native Turkish speakers, were illiterate and/ or who had physical handicaps (such as deaf-mute) were excluded. Eighteen participants did not answer all survey questions and were excluded. All participants volunteered to sign a consent form. The survey was first piloted on 20 participants and there was no need for amendments; it could be completed in about 18 minutes.

Statistical analysis. The data were analyzed using the Statistical Package for Social Sciences for Windows, version 18.0 (IBM Inc, Chicago, Ill, USA). Responses to the survey items were described as counts and percentages for categorical variables and as means and standard deviations for continuous variables. The Chi-square test was used to test the significant difference between categorical variables at $p<0.05$ level of significance. In these analyses, $p<0.05$ was considered significant.

Results. The mean age of the participants was 39.56 \pm 14.16 (min: 18, max:79) years. The distribution of the sociodemographic characteristics is given in Table 1. Fifty-seven (38\%) of the participants reported a monthly income lower than the official minimum wage. Seventy-five $(50 \%)$ of the participants had never been in the pathology laboratory before. Regarding the specimens brought to the laboratory, 79 (52.7\%) belonged to the person and $71(47.3 \%)$ to a first-degree relative. Thirteen $(8.7 \%)$ of the specimens had a tumor

Table 1 - Distribution of the sociodemographic characteristics of the participants.

\begin{tabular}{lc}
\hline Features & $\mathbf{n}(\%)$ \\
\hline Age (year) & $39.56 \pm 14.16^{*}$ \\
Gender & \\
Female & $79(52.7)$ \\
Male & $71(47.3)$ \\
Educational status & \\
$\quad$ Primary school & $47(31.3)$ \\
Secondary school & $15(10.0)$ \\
High school & $38(25.3)$ \\
University & $50(33.3)$ \\
Working status & \\
Working & $72(48.0)$ \\
Not working & $78(52.0)$ \\
\hline \multicolumn{2}{c}{${ }^{2}$ Mean \pm standard deviation }
\end{tabular}

mass. The remaining specimens were related with the following systems: 23 (15.3\%) gastrointestinal system, $15(10 \%)$ skin, $9(6 \%)$ gynecological, 7 (4.7\%) breast, $7(4.7 \%)$ lung, and 5 (3.3\%) soft tissue. Eighty-two $(54.7 \%)$ participants believed that the pieces were discarded after preparation of the pathology report.

Distribution of other study variables can be seen in Table 2. Ninety-eight $(65.3 \%)$ of participants believed that they did not have the right to choose their pathologist. Sixty-four $(42.7 \%)$ believed that all

Table 2 - Responses to the multiple choice questions about pathology.

\begin{tabular}{|c|c|}
\hline Questions & $\mathrm{n}(\%)$ \\
\hline \multicolumn{2}{|l|}{ Staff working in the pathology laboratory * } \\
\hline Dietician & 0 \\
\hline Emergency medical technician & $4 \quad(2.7)$ \\
\hline Pathology technician & $100(66.7)$ \\
\hline Nurse & $27(18.0)$ \\
\hline Paramedic & $2(1.3)$ \\
\hline Pathologist & $112(74.7)$ \\
\hline Medical secretary & $39(26.0)$ \\
\hline Psychologist & 0 \\
\hline \multicolumn{2}{|l|}{$\begin{array}{l}\text { Which specimens are examined in the } \\
\text { pathology laboratory? * }\end{array}$} \\
\hline $\begin{array}{l}\text { Tissue/organs extracted with micro or } \\
\text { macro surgery }\end{array}$ & $115(76.7)$ \\
\hline Cells collected or spilled spontaneously & $87(58.0)$ \\
\hline Body fluids such as urine and sputum & $38(25.3)$ \\
\hline Swabs taken from the cervix & $60(40.0)$ \\
\hline Other & $28(18.7)$ \\
\hline \multicolumn{2}{|l|}{ When I get my pathology report, I will* } \\
\hline Apply to my specialist doctor & $146(97.3)$ \\
\hline Search in the internet sources & $7 \quad(4.7)$ \\
\hline Ask to relatives and friends & $1 \quad(0.7)$ \\
\hline Apply to my family doctor & $5(3.3)$ \\
\hline No idea & $2(1.3)$ \\
\hline \multicolumn{2}{|l|}{$\begin{array}{l}\text { The feelings of a patient delivering his/her } \\
\text { material to the pathology laboratory* }\end{array}$} \\
\hline Anxious & $95(63.3)$ \\
\hline Excited & $21(14.0)$ \\
\hline Curious & $53(35.3)$ \\
\hline Desperate & $3(2.0)$ \\
\hline Calm & $2(1.3)$ \\
\hline \multicolumn{2}{|l|}{$\begin{array}{l}\text { Factors affecting due date of the biopsy } \\
\text { report * }\end{array}$} \\
\hline The nature of the specimen & $73(48.7)$ \\
\hline The nature of the disease & $92(61.3)$ \\
\hline The nature of the pathology laboratory & $60(40.0)$ \\
\hline Other & $29(19.3)$ \\
\hline \multicolumn{2}{|l|}{$\begin{array}{l}\text { After the pathology report concluded, the } \\
\text { specimen should be examined in another } \\
\text { center if } *\end{array}$} \\
\hline Concluded to be benign & $7(4.7)$ \\
\hline Concluded to be malignant & $81(54.0)$ \\
\hline Insufficient specimen & $13(8.7)$ \\
\hline Physician recommends & $83(55.3)$ \\
\hline
\end{tabular}


Table 3 - Responses to the "true or false" questions about pathology.

\begin{tabular}{|c|c|c|c|}
\hline Questions & True & False & No idea \\
\hline It is not necessary to complete the medical school to become a pathologist $\left(\mathrm{F}^{*}\right)$ & $24(16.0)$ & $98(65.3)$ & $28(18.7)$ \\
\hline As a result of pathological examination, diseases will be diagnosed $\left(\mathrm{T}^{* *}\right)$ & $109(72.7)$ & $24(16.0)$ & $17(11.3)$ \\
\hline Pathological examination does not guide the treatment of patients $(\mathrm{F})$ & $27(18.0)$ & $102(68.0)$ & $21(14.0)$ \\
\hline $\begin{array}{l}\text { Pathological examination starts with the excretion of cells or tissue samples or organs from the } \\
\text { body }(\mathrm{T})\end{array}$ & $114(76.0)$ & $10(6.7)$ & $26(17.3)$ \\
\hline $\begin{array}{l}\text { In order to perform the technical procedures in the pathology, a minimum period of } 24 \text { hours } \\
\text { is required after the sample has been taken }(T)\end{array}$ & $73(48.7)$ & $26(17.3)$ & $51(34.0)$ \\
\hline $\begin{array}{l}\text { The course of the operation can be changed with a pathological diagnosis given to the patient } \\
\text { during the surgery }(\mathrm{T})\end{array}$ & 79 (52.7) & $27(18.0)$ & $44(29.3)$ \\
\hline The pathologist is a medical doctor. $(\mathrm{T})$ & $91(60.7)$ & $20(13.3)$ & $39(26.0)$ \\
\hline The diagnosis could be given after 3 hours most probably $(\mathrm{F})$ & $29(19.3)$ & $54(36.0)$ & $67(44.7)$ \\
\hline $\begin{array}{l}\text { Cancer can be detected before causing any symptoms and complaints with a pathological } \\
\text { examination }(\mathrm{T})\end{array}$ & $92(61.3)$ & $22(14.7)$ & $36(24.0)$ \\
\hline 'Frozen section' is the process of rapid evaluation of the sample taken during the surgery $(\mathrm{T})$ & $61(40.7)$ & $10(6.6)$ & $79(52.7)$ \\
\hline Paraffin blocks and tissues should be given to the patient when necessary. (T) & $64(42.7)$ & $36(24.0)$ & $50(33.3)$ \\
\hline Pathologists diagnose the tissues by microscopy $(\mathrm{T})$ & $84(56.0)$ & $17(11.3)$ & $49(32.7)$ \\
\hline 4 years of postgraduate training is required to become a pathologist $(\mathrm{T})$ & $77(51.3)$ & $7(4.7)$ & $66(44.0)$ \\
\hline $\begin{array}{l}\text { Pathology is a branch of medicine that tries to diagnose diseases by examining samples } \\
\text { extracted from tissues and organs predicted to be involved }(T)\end{array}$ & $122(81.3)$ & $1(0.7)$ & $27(18.0)$ \\
\hline
\end{tabular}

Table 4 - Comparison of feelings of participants and awareness about pathology with educational levels of the participants.

\begin{tabular}{|c|c|c|c|c|c|c|}
\hline Staff working in the pathology laboratory & Primary school & Secondary school & High school & University & $\chi^{2}$ & $P$-value \\
\hline Pathology technician $\left(\mathrm{T}^{*}\right)$ & $28(28.0)$ & $7(7.0)$ & $27(27.0)$ & $38(38.0)$ & 5.969 & 0.113 \\
\hline Nurse $\left(\mathrm{F}^{* *}\right)$ & $8(29.6)$ & $1(3.7)$ & $4(14.8)$ & $14(51.9)$ & 6.316 & 0.097 \\
\hline Pathologist (T) & $29(25.9)$ & $11(9.8)$ & $30(26.8)$ & $42(37.5)$ & 6.755 & 0.08 \\
\hline Medical secretary $(\mathrm{T})$ & $5(12.8)$ & $7(17.9)$ & $11(28.2)$ & $16(41.0)$ & 10.920 & 0.012 \\
\hline \multicolumn{7}{|l|}{ Specimens examined in the pathology laboratory } \\
\hline $\begin{array}{l}\text { Tissue/organs extracted with micro or macro } \\
\text { surgery }(\mathrm{T})\end{array}$ & $34(29.6)$ & $10 \quad(8.7)$ & $27(23.5)$ & $44(38.3)$ & 6.034 & 0.11 \\
\hline Cells collected or spilled spontaneously $(\mathrm{T})$ & $22(25.3)$ & $7(8.0)$ & $25(28.7)$ & $33(37.9)$ & 5.468 & 0.14 \\
\hline Body fluids such as urine and sputum (T) & $11(28.9)$ & $2(5.3)$ & $9(23.7)$ & $16(42.1)$ & 2.573 & 0.462 \\
\hline Swabs taken from the cervix $(\mathrm{T})$ & $18(30.0)$ & $3(5.0)$ & $12(20.0)$ & $27(45.0)$ & 7.942 & 0.047 \\
\hline \multicolumn{7}{|l|}{$\begin{array}{l}\text { The possible feelings of a patient delivering his/ } \\
\text { her material to the pathology laboratory }\end{array}$} \\
\hline Anxious & $33(34.7)$ & $9 \quad(9.5)$ & $19(20.0)$ & $34(35.8)$ & 4.340 & 0.227 \\
\hline Excited & $7(33.3)$ & $2(9.5)$ & $4(19.0)$ & $8(38.1)$ & 0.607 & 0.895 \\
\hline Curious & $10(18.9)$ & $4(7.5)$ & $20(37.7)$ & $19(35.8)$ & 9.814 & 0.020 \\
\hline \multicolumn{7}{|l|}{$\begin{array}{l}\text { The factors affecting the preparation duration of } \\
\text { the biopsy report }\end{array}$} \\
\hline The nature of the specimen $(\mathrm{T})$ & $11(15.1)$ & $5(6.8)$ & $24(32.9)$ & $33(45.2)$ & 23.475 & 0.000 \\
\hline The nature of the disease $(\mathrm{T})$ & $27(29.3)$ & $9 \quad(9.8)$ & $23(25.0)$ & $33(35.9)$ & 0.785 & 0.853 \\
\hline The nature of the pathology laboratory $(\mathrm{T})$ & $18(30.0)$ & $6(10.0)$ & $14(23.3)$ & $22(36.7)$ & 0.546 & 0.909 \\
\hline $\begin{array}{l}\text { All diseases could be diagnosed in pathology } \\
100 \%(\mathrm{~F})\end{array}$ & $28(43.8)$ & $6(9.4)$ & $14(21.9)$ & $16(25.0)$ & 8.390 & 0.039 \\
\hline All extracted tissues should be examined $(\mathrm{T})$ & $39(37.5)$ & $11(10.6)$ & $25(24.0)$ & $29(27.9)$ & 7.787 & 0.05 \\
\hline $\begin{array}{l}\text { Final diagnosis is made by pathological } \\
\text { examination }(T)\end{array}$ & $36(33.0)$ & $13(11.9)$ & $25(22.9)$ & $35(32.1)$ & 12.916 & 0.44 \\
\hline $\begin{array}{l}\text { Pathology results guide the treatment of the } \\
\text { patients }(\mathrm{T})\end{array}$ & $26(25.5)$ & $8(7.8)$ & $27(26.5)$ & $41(40.2)$ & 13.304 & 0.03 \\
\hline
\end{tabular}


Pathology awareness in patients ... Findik \& Cihan

Table 5 - Correct response rates for the awareness questions and the relations with respondents' characteristics.

\begin{tabular}{|c|c|c|c|c|c|c|c|c|c|c|c|c|c|c|c|c|c|}
\hline \multirow[t]{2}{*}{ Response } & \multicolumn{4}{|c|}{ Age } & \multicolumn{4}{|c|}{ Gender } & \multicolumn{4}{|c|}{ Educational status } & \multicolumn{4}{|c|}{ Working status } & \multirow{2}{*}{$\begin{array}{c}\text { Total } \\
\text { correct } \\
\text { answers }\end{array}$} \\
\hline & $\begin{array}{c}<37^{*} \\
\text { years old }\end{array}$ & $\begin{array}{c}\geq 37 \\
\text { years } \\
\text { old }\end{array}$ & $x^{2}$ & $P$-value & Female & Male & $x^{2}$ & & $\begin{array}{l}\text { Primary/ } \\
\text { secondary } \\
\text { school }\end{array}$ & $\begin{array}{l}\text { High } \\
\text { school/ } \\
\text { University }\end{array}$ & $x^{2}$ & $P$-value & Working & $\begin{array}{c}\text { Not } \\
\text { working }\end{array}$ & $x^{2}$ & $P$-value & \\
\hline $\begin{array}{l}\text { It is not necessary to } \\
\text { complete the medical } \\
\text { school to become a } \\
\text { pathologist }\end{array}$ & $\begin{array}{c}50 \\
(33.3)\end{array}$ & $\begin{array}{c}48 \\
(32.0)\end{array}$ & 0.025 & 0.874 & $\begin{array}{c}57 \\
(38.0)\end{array}$ & $\begin{array}{c}41 \\
(27.3)\end{array}$ & 2.820 & 0.093 & $\begin{array}{c}40 \\
(26.7)\end{array}$ & $\begin{array}{c}58 \\
(38.6)\end{array}$ & 0.000 & 0.998 & $\begin{array}{c}45 \\
(30.0)\end{array}$ & $\begin{array}{c}53 \\
(35.3)\end{array}$ & 0.280 & 0.597 & $\begin{array}{c}98 \\
(65.3)\end{array}$ \\
\hline $\begin{array}{l}\text { As a result of } \\
\text { pathological } \\
\text { examination, diseases } \\
\text { will be diagnosed }\end{array}$ & $\begin{array}{c}57 \\
(38.0)\end{array}$ & $\begin{array}{c}52 \\
(34.7)\end{array}$ & 0.000 & 0.907 & $\begin{array}{c}58 \\
(38.7)\end{array}$ & $\begin{array}{c}51 \\
(34.0)\end{array}$ & 0.001 & 0.973 & $\begin{array}{c}49 \\
(32.7)\end{array}$ & $\begin{array}{c}60 \\
(40.0)\end{array}$ & 1.644 & 0.200 & $\begin{array}{c}51 \\
(34.0)\end{array}$ & $\begin{array}{c}58 \\
(38.7)\end{array}$ & 0.090 & 0.764 & $\begin{array}{c}109 \\
(72.7)\end{array}$ \\
\hline $\begin{array}{l}\text { Pathological examination } \\
\text { does not guide the } \\
\text { treatment of patients }\end{array}$ & $\begin{array}{c}57 \\
(38.0)\end{array}$ & $\begin{array}{c}45 \\
(30.0)\end{array}$ & 0.950 & 0.330 & $\begin{array}{c}57 \\
(38.0)\end{array}$ & $\begin{array}{c}45 \\
(30.0)\end{array}$ & 1.469 & 0.225 & $\begin{array}{c}34 \\
(22.7)\end{array}$ & $\begin{array}{c}68 \\
(45.3)\end{array}$ & 7.413 & 0.006 & $\begin{array}{c}52 \\
(34.7)\end{array}$ & $\begin{array}{c}50 \\
(33.3)\end{array}$ & 0.792 & 0.374 & $\begin{array}{c}102 \\
(68.0)\end{array}$ \\
\hline $\begin{array}{l}\text { Pathological examination } \\
\text { starts with the excretion } \\
\text { of cells or tissue samples } \\
\text { or organs from the body }\end{array}$ & $\begin{array}{c}56 \\
(37.3)\end{array}$ & $\begin{array}{c}58 \\
(38.7)\end{array}$ & 1.132 & 0.287 & $\begin{array}{c}62 \\
(41.3)\end{array}$ & $\begin{array}{c}52 \\
(34.7)\end{array}$ & 0.313 & 0.576 & $\begin{array}{c}49 \\
(32.7)\end{array}$ & $\begin{array}{c}65 \\
(43.3)\end{array}$ & 0.287 & 0.592 & $\begin{array}{c}57 \\
(38.0)\end{array}$ & $\begin{array}{c}57 \\
(38.0)\end{array}$ & 0.464 & 0.496 & $\begin{array}{c}114 \\
(76.0)\end{array}$ \\
\hline $\begin{array}{l}\text { In order to perform the } \\
\text { technical procedures } \\
\text { in the pathology, a } \\
\text { minimum period of } 24 \\
\text { hours is required after } \\
\text { the sample has been } \\
\text { taken }\end{array}$ & $\begin{array}{c}34 \\
(22.7)\end{array}$ & $\begin{array}{c}39 \\
(26.0)\end{array}$ & 1.677 & 0.195 & $\begin{array}{c}38 \\
(25.3)\end{array}$ & $\begin{array}{c}35 \\
(23.4)\end{array}$ & 0.021 & 0.884 & $\begin{array}{c}33 \\
(22.0)\end{array}$ & $\begin{array}{c}40 \\
(26.7)\end{array}$ & 0.879 & 0.348 & $\begin{array}{c}35 \\
(23.4)\end{array}$ & $\begin{array}{c}38 \\
(25.3)\end{array}$ & 0.000 & 0.990 & $\begin{array}{c}73 \\
(48.7)\end{array}$ \\
\hline $\begin{array}{l}\text { The course of the } \\
\text { operation can be changed } \\
\text { with a pathological } \\
\text { diagnosis given to the } \\
\text { patient during the } \\
\text { surgery }\end{array}$ & $\begin{array}{c}39 \\
(26.0)\end{array}$ & $\begin{array}{c}40 \\
(26.7)\end{array}$ & 1.464 & 0.496 & $\begin{array}{c}45 \\
(30.0)\end{array}$ & $\begin{array}{c}34 \\
(22.7)\end{array}$ & 1.235 & 0.266 & $\begin{array}{c}31 \\
(20.7)\end{array}$ & $\begin{array}{c}48 \\
(32.0)\end{array}$ & 0.301 & 0.583 & $\begin{array}{c}40 \\
(26.7)\end{array}$ & $\begin{array}{c}39 \\
(26.0)\end{array}$ & 1.464 & 0.496 & $\begin{array}{c}79 \\
(52.7)\end{array}$ \\
\hline $\begin{array}{l}\text { The pathologist is a } \\
\text { medical doctor }\end{array}$ & $\begin{array}{c}45 \\
(30.0)\end{array}$ & $\begin{array}{c}46 \\
(30.7)\end{array}$ & 0.602 & 0.438 & $\begin{array}{c}50 \\
(33.3)\end{array}$ & $\begin{array}{c}41 \\
(27.4)\end{array}$ & 0.482 & 0.488 & $\begin{array}{c}34 \\
(22.7)\end{array}$ & $\begin{array}{c}57 \\
(38.0)\end{array}$ & 1.117 & 0.291 & $\begin{array}{c}47 \\
(31.3)\end{array}$ & $\begin{array}{c}44 \\
(29.4)\end{array}$ & 1.234 & 0.267 & $\begin{array}{c}91 \\
(60.7)\end{array}$ \\
\hline $\begin{array}{l}\text { The diagnosis could be } \\
\text { given after } 3 \text { hours most } \\
\text { probably }\end{array}$ & $\begin{array}{c}28 \\
(18.7)\end{array}$ & $\begin{array}{c}26 \\
(17.3)\end{array}$ & 0.001 & 0.978 & $\begin{array}{c}26 \\
(17.3)\end{array}$ & $\begin{array}{c}28 \\
(18.7)\end{array}$ & 0.691 & 0.406 & $\begin{array}{c}27 \\
(18.0)\end{array}$ & $\begin{array}{c}27 \\
(18.0)\end{array}$ & 2.085 & 0.149 & $\begin{array}{c}26 \\
(17.3)\end{array}$ & $\begin{array}{c}28 \\
(18.7)\end{array}$ & 0.001 & 0.978 & $\begin{array}{c}54 \\
(36.0)\end{array}$ \\
\hline $\begin{array}{l}\text { Cancer can be detected } \\
\text { before causing any } \\
\text { symptoms and } \\
\text { complaints with a } \\
\text { pathological examination }\end{array}$ & $\begin{array}{c}48 \\
(32.0)\end{array}$ & $\begin{array}{c}44 \\
(29.3)\end{array}$ & 0.003 & 0.957 & $\begin{array}{c}52 \\
(34.7)\end{array}$ & $\begin{array}{c}40 \\
(26.6)\end{array}$ & 1.418 & 0.234 & $\begin{array}{c}36 \\
(24.0)\end{array}$ & $\begin{array}{c}56 \\
(37.3)\end{array}$ & 0.270 & 0.603 & $\begin{array}{c}41 \\
(27.3)\end{array}$ & $\begin{array}{c}51 \\
(34.0)\end{array}$ & 1.125 & 0.289 & $\begin{array}{c}92 \\
(61.3)\end{array}$ \\
\hline $\begin{array}{l}\text { 'Frozen section' is } \\
\text { the process of rapid } \\
\text { evaluation of the sample } \\
\text { taken during the surgery }\end{array}$ & $\begin{array}{c}28 \\
(18.7)\end{array}$ & $\begin{array}{c}33 \\
(22.0)\end{array}$ & 1.532 & 0.216 & $\begin{array}{c}27 \\
(18.0)\end{array}$ & $\begin{array}{c}34 \\
(22.7)\end{array}$ & 2.913 & 0.088 & $\begin{array}{c}29 \\
(19.3)\end{array}$ & $\begin{array}{c}32 \\
(21.4)\end{array}$ & 1.634 & 0.201 & $\begin{array}{c}29 \\
(19.3)\end{array}$ & $\begin{array}{c}32 \\
(21.4)\end{array}$ & 0.009 & 0.926 & $\begin{array}{c}61 \\
(40.7)\end{array}$ \\
\hline $\begin{array}{l}\text { Paraffin blocks and } \\
\text { tissues should be given } \\
\text { to the patient when } \\
\text { necessary }\end{array}$ & $\begin{array}{c}34 \\
(22.7)\end{array}$ & $\begin{array}{c}30 \\
(20.0)\end{array}$ & 0.057 & 0.812 & $\begin{array}{c}33 \\
(22.0)\end{array}$ & $\begin{array}{c}31 \\
(20.7)\end{array}$ & 0.055 & 0.815 & $\begin{array}{c}29 \\
(19.3)\end{array}$ & $\begin{array}{l}35 \\
(23.4)\end{array}$ & 0.729 & 0.393 & $\begin{array}{c}30 \\
(20.0)\end{array}$ & $\begin{array}{c}34 \\
(22.7)\end{array}$ & 0.057 & 0.812 & $\begin{array}{c}64 \\
(42.7)\end{array}$ \\
\hline $\begin{array}{l}\text { Pathologists diagnose the } \\
\text { tissues by microscopy }\end{array}$ & $\begin{array}{c}43 \\
(28.7)\end{array}$ & $\begin{array}{c}41 \\
(27.3)\end{array}$ & 0.050 & 0.823 & $\begin{array}{c}44 \\
(29.3)\end{array}$ & $\begin{array}{c}40 \\
(26.7)\end{array}$ & 0.006 & 0.937 & $\begin{array}{c}35 \\
(23.3)\end{array}$ & $\begin{array}{c}49 \\
(32.7)\end{array}$ & 0.009 & 0.925 & $\begin{array}{c}42 \\
(28.0)\end{array}$ & $\begin{array}{c}42 \\
(28.0)\end{array}$ & 0.306 & 0.580 & $\begin{array}{c}84 \\
(56.0)\end{array}$ \\
\hline $\begin{array}{l}4 \text { years of postgraduate } \\
\text { training is required to } \\
\text { become a pathologist }\end{array}$ & $\begin{array}{c}37 \\
(24.7)\end{array}$ & $\begin{array}{c}40 \\
(26.7)\end{array}$ & 0.988 & 0.320 & $\begin{array}{c}39 \\
(26.0)\end{array}$ & $\begin{array}{c}38 \\
(25.3)\end{array}$ & 0.258 & 0.611 & $\begin{array}{c}32 \\
(21.3)\end{array}$ & $\begin{array}{c}45 \\
(30.0)\end{array}$ & 0.003 & 0.954 & $\begin{array}{c}34 \\
(22.7)\end{array}$ & $\begin{array}{c}43 \\
(28.7)\end{array}$ & 0.937 & 0.333 & $\begin{array}{c}77 \\
(51.3)\end{array}$ \\
\hline $\begin{array}{l}\text { Pathology is a branch } \\
\text { of medicine that tries } \\
\text { to diagnose diseases } \\
\text { by examining samples } \\
\text { extracted from tissues } \\
\text { and organs predicted to } \\
\text { be involved }\end{array}$ & $\begin{array}{c}61 \\
(40.7)\end{array}$ & $\begin{array}{c}61 \\
(40.7)\end{array}$ & 0.662 & 0.416 & $\begin{array}{c}70 \\
(46.7)\end{array}$ & $\begin{array}{c}52 \\
(34.6)\end{array}$ & 4.849 & 0.028 & $\begin{array}{c}50 \\
(33.3)\end{array}$ & $\begin{array}{c}72 \\
(48.0)\end{array}$ & 0.000 & 0.856 & $\begin{array}{c}59 \\
(39.3)\end{array}$ & $\begin{array}{c}63 \\
(42.0)\end{array}$ & 0.000 & 0.854 & $\begin{array}{c}122 \\
(1.3)\end{array}$ \\
\hline
\end{tabular}


diseases could be diagnosed in the pathology laboratory with a $100 \%$ certainty, and $46(30.7 \%)$ thought that there was no need to examine all the tissues extracted. Responses to the true or false questions about pathology are listed in Table 3.

When gender was compared, reported anxiety was significantly higher among female respondents $(p=0.043)$.

The correct response rate of females was higher than males for the questions "the pathologist works in the laboratory" $(p=0.014)$, "swabs taken from the cervix are examined" ( $p=0.000)$, and "pathology is a branch of medicine that diagnoses the diseases" $(p=0.021)$. Males knew the meaning of "frozen section" in higher rates according to females $(p=0.036)$.

A comparison of awareness about pathology with the educational level of the participants is given in Table 4.

Correct response rate for the awareness questions and their relation with respondents' characteristics are given in Table 5. The awareness of respondents has not influenced their feelings.

When compared by economic situation, the responses of those earning under the minimum wage were significantly less accurate $(p=0.015)$.

Patients with higher income levels were aware that not all diseases could be diagnosed $(p=0.036)$ and that the final pathological diagnosis report could not be given in a short time such as 3 hours $(p=0.021)$. Those with higher incomes thought that the quality of the extracted tissue affected reporting duration $(p=0.003)$, while those with lower incomes believed that the character of the disease was a bigger factor $(p=0.04)$. Those with lower incomes thought that all extracted tissues should be examined in the pathology laboratory $(p=0.004)$.

Applying to their family physician after receiving the pathology report, the rate of curious feelings while delivering the specimen, and the rate of not knowing the content of the specimen they brought to the laboratory were significantly higher in those who have not been to the pathology laboratory before $(p=0.008, p=0.026$, and $p=0.000)$.

Knowing "that the medical secretary can work in the laboratory," "that the tissue or organs removed by a small or large operation from the body were examined," and "the rate of knowing they have the right to choose a pathologist" was higher in the employee participants ( $p=0.004, \quad p=0.041$, and $p=0.000$, respectively). Employees prefer to take their specimen to another pathology center if the result is malignant $(p=0.020)$ and others prefer to deliver to another center if their physician recommends it $(p=0.010)$. Those who brought their own tissues stated that if it is suggested, they could take it to another center for consultation $(p=0.039)$. Interestingly a high proportion of patients could not specify their specimen content $(p=0.003)$.

Discussion. Pathology is a medical discipline that examines the causes of diseases, the way they affect tissues and organs, and especially the morphology of diseased tissues and organs. ${ }^{1-4}$ The aim of this study was to investigate the awareness of patients and their relatives about pathology and related laboratory procedures.

Today, a pathological examination is required and often essential for the definitive diagnosis of many diseases, especially the diagnosis of tumors. It is clear that pathologists carry a major responsibility for rendering diagnoses and providing prognostic and predictive information. Any mistake in this exercise can result in serious consequences. If these tasks are not done properly, clinicians may be misled, and patients will subsequently suffer from inappropriate treatment. ${ }^{2-4}$ In our survey, about one-third of participants did not know that all substances that are excreted from the body must be examined.

The pathologist, pathology technician, medical secretary, and assistant staff are employed in the pathology laboratory. ${ }^{17}$ Some participants believed that there were also nurses $(18.0 \%)$, paramedics $(1.3 \%)$, or emergency medical technicians $(2.7 \%)$ working in the pathology laboratory.

Samples to be examined in the pathology laboratory are evaluated in two groups that consist "of cells: cells" either obtained from the body by a needle, spontaneously spilled, or from other body fluids, as well as surgically dissected tissues or organs. ${ }^{2,4}$ A substantial number of participants did not know that materials such as body fluids like urine and sputum (74.7\%), swabs taken from the cervix $(60.0 \%)$, and cells collected or spilled spontaneously (42\%) could be examined pathologically.

In Turkey, after 6 years of undergraduate medical school training, graduates take an exam called Examination for Specialty in Medicine (TUS) to determine their placements as residents in postgraduate specialty teaching programs. The training period to become a specialist in pathology is 4 years. $^{3}$ In our survey, $65.3 \%$ of participants knew that medical school graduation was required to become a pathology specialist, and $51.3 \%$ could correctly identify the duration of the specialty training. However, 39.3\% of the participants did not know that pathologists were medical doctors.

When trying to determine a diagnosis, pathologists examine the samples excreted from tissues and organs that are suspected to be involved in the disease. First, 
a macroscopic examination is done, followed by a microscopic examination, which usually takes up most of the pathologists' time. ${ }^{2-5}$ Interestingly, $44.0 \%$ of the participants did not know that pathologists based their decisions on microscopic examinations.

At the end of the process, the pathologist prepares a report that may include a diagnosis or, when no clear-cut diagnosis can be made, a list of differentials and recommendations. ${ }^{3-6,17}$ Participants had relatively high expectations from the pathology department; only 86 participants $(57.3 \%)$ knew that not all diseases could be diagnosed $100 \%$ of the time.

The rate of those who knew that after receiving the pathology report, the person should consult with his or her doctor was very high (97.3\%). In our study, the rate of application to the family physician was significantly higher in those who had not previously been to the pathology laboratory.

There are around 10-15 hours of technical processing time for a pathological examination, ${ }^{2-5,17}$ However, $48.7 \%$ of the participants thought that the duration of the technical procedures was at least 24 hours, while $51.3 \%$ had no idea what the duration was. Under normal conditions, the pathology result can be given after one day at best. Nevertheless, $19.3 \%$ of the participants thought that a diagnosis could be reached most probably within three hours. Also, the percentage of those who did not have any idea about this issue was quite high (44.7\%).

Many factors, such as the nature of the pathological sample or the disease and the conditions of the pathology laboratory, may affect the reporting period. ${ }^{2-5}$ Approximately half of the participants assumed that the nature of the sample had no effect on the diagnostic process, and $40 \%$ knew that the nature of the pathology laboratory had an influence.

Sometimes during a surgical intervention, a diagnosis may be needed within a very short period, such as when there is the possibility of changing the course of the surgery. In these cases, the excised tissues are prepared and examined by using accelerated methods called "frozen section," by which an opinion can be reached within 10-15 minutes. ${ }^{2,18}$ The rates of the participants who knew the meaning of "frozen section" and that its results could change the course of the treatment were $40.7 \%$ and $52.7 \%$. The public should become fully aware of the complexities involved in the interpretation of difficult cases in pathology. Physicians engaged in the diagnosis and management of cancer can play a critical role in educating the public by encouraging patients to understand the pathology of their disease and seek a second opinion about the accuracy of their pathology diagnosis. ${ }^{4-10}$ Samples stored in the pathology laboratory are supposed to be available for the patient when requested, ${ }^{3}$ but only $42.7 \%$ of participants were aware of this rule.

When we reviewed the feelings of the people who went to the pathology laboratory, anxiety appeared to be higher among women. Concerning the level of knowledge and awareness on some variables, women were superior compared to men. These results are supposedly due to the differences in emotions and awareness among women compared to men. ${ }^{19-21}$ In addition, considering that two-thirds of the participating women did not work, TV programs and other media about health might have contributed to this finding.

According to the definition of the European Health Literacy (HLS-EU) consortium, health literacy and general literacy are related. ${ }^{15}$ Similarly in our study, the rate of correct answers increased parallel to the level of education. In a study conducted in the United States, people with low health literacy were found to consume health services more than others. ${ }^{22}$ In our study, primary school graduates alleged that all materials removed from the body should be examined, which suggests that they tend to make more frequent use of health services.

In a study with primary health care patients, it was found that functional health literacy significantly differed according to the patients' residence, age, marital status, occupation, education, financial situation, health perception, and the presence of chronic conditions. ${ }^{23}$ In this study, the rate of correct answers was higher among working and high-income participants.

According to overall literacy rates, Turkey is located behind the developed countries and therefore has low health literacy. ${ }^{24}$ In 2009, the first field trial with 4924 people based on "European Health Literacy Survey" demonstrated that general health literacy index has been 30.4/50 in Turkey. Only one-third of the population had adequate health literacy, suggesting that health literacy needs to be improved in Turkey. To increase the level of health literacy, it was concluded that the education level and economic parameters should be increased first. ${ }^{25}$

To improve health literacy, every platform giving health care is very crucial, and pathology is just one of these areas. According to the study in Canada, health literacy knowledge and awareness should be in the undergraduate curriculum of medical students and doctors. ${ }^{26}$ Therefore, this survey about pathology should be applied to other branches with a comparison of the results.

Study limitation. This study is performed in only one pathology laboratory in Turkey. Therefore, it may not represent the whole population. 
This is a pioneering study analyzing the public's understanding of pathology services not only in national but also in the international literature.

In conclusion, it was determined that the patients knew a little about anatomical pathology science and pathology laboratory procedures. The participants were patients and/or relatives directed to the pathology laboratory by the clinicians. We can expect that awareness would be lower if the survey is applied to healthy individuals who had never come to the pathology department. The discrepancies in understanding identified in Turkey, likely exist everywhere. The results of this pioneering study in the national and international platforms, are quite striking.

Acknowledgment. The authors gratefully acknowledge Scribendi Inc. (www.scribendi.com) for English language editing.

\section{References}

1. Hébert TM, Cole A, Panarelli N, Hu S, Jacob J, Ahlstedt J et al. Training the Next Generation of Pathologists: A Novel Residency Program Curriculum at Montefiore Medical Center/ Albert Einstein College of Medicine. Acad Pathol 2019; 6: 2374289519848099.

2. Lewandrowski K, Black-Schaffer S. Utilization management in anatomic pathology. Clinica Chimica Acta 2014; 427: 183-187.

3. Celasun B. Patoloji'ye hoşgeldiniz! [blog]. Nasıl Tanı Koyuyoruz? Patolojide tanı koyma süreci üzerine görüssler. [Upadted 2019. Cited January 2019]. Available from: URL:'https://patoloji. gen.tr/nasil-tani-koyuyoruz-patolojide-tani-koyma-sureciuzerine-gorusler/'

4. Masood S, Dabbs DJ. Patient Safety in Breast Pathology. In: Dabbs DJ, editor. Breast Pathology. 2 ed: Elsevier; 2017. p. $65-75$.

5. Weindel MHB. Establishing A Molecular Diagnostics Laboratory. Henry's Clinical Diagnosis and Management by Laboratory Methods. Elsevier; 2016. p. 1360-76.e1

6. Centre for International Economics (CIE). The Economic Value of Pathology: Achieving Better Health, and A Better Use of Health Resources. [Updated 2019. Cited September 2019]. Available from: http://www.thecie.com.au/wp-content/ uploads/2016/04/Economic-value-of-pathology_-FinalReport-April-2016.pdf

7. IVD Australia. Value of Pathology. [Updated 2019. Cited September 2019]. Available from: https://www.ivd.org.au/ advocacy/value-of-pathology/

8. London Agency. Pathology Awarenesss Australia. [Accessed September 2019]. Available from: http://www.londonagency. com.au/clients/know-pathology/

9. National Coalition of Public Pathology (NCOPP). Public Pathology Australia. What is pathology? [Accessed September 2019]. Available from: http://public pathology.org.au/about/ what-is-pathology/

10. Pathology Awareness Australia Limited (PAA). What is pathology? [Accessed September 2019]. Available from: http:// know pathology.com.au/what-is-pathology/

11. https://dosyamerkez.saglik.gov.tr/Eklenti/28322,sas-odhs-kitonizlemepdf.pdf?0. Accessed August 2019
12. Koh HK, Rudd RE. The arc of health literacy. JAMA 2015; 314 : 1225-1226.

13. Hernandez L, French M, Parker R. Roundtable on health literacy: issues and impact. Stud Health Technol Inform 2017; 240: 169-185.

14. Centers for Disease Control and Prevention. Improving Health Literacy for Older Adults: Expert Panel Report 2009. Atlanta: U.S. Department of Health and Human Services; 2009. Available from: https://www.cdc.gov/healthliteracy/pdf/ olderadults-508.pdf

15. Sørensen K, Pelikan JM, Röthlin F, Ganahl K, Slonska Z, Doyle $\mathrm{G}$, et al. HLS-EU Consortium. Health literacy in Europe: comparative results of the European health literacy survey (HLS-EU). Eur J Public Health 2015; 25: 1053-1058.

16. Garcia-Codina O, Juvinyà-Canal D, Amil-Bujan P, BertranNoguer C, González-Mestre MA, Masachs-Fatjo E et al. Determinants of health literacy in the general population: results of the Catalan health survey. BMC Public Health 2019; 19: 1122.

17. The Royal College of Pathologists of Australasia (RCPA). Who works in Pathology and what do they do? [Accessed August 2019]. Available from: https://www.rcpa.edu.au/ getattachment/90c9d66e-e7db-4b30-87b5-2105244a2149/ FctSht-1-Work-In-Path.aspx

18. Preeti A, Sameer G, Kulranjan S, Arun Abhinav S, Preeti R, Sunita Y, et al. Intra-operative frozen sections: experience at a tertiary care centre. Asian Pac J Cancer Prev 2016; 17: 5057-5061.

19. Brody, L. R., Hall, J. A., Stokes, L. R. (2016). Gender and emotion: Theory, findings and content. In Feldman Barrett, L., Lewis, M., Haviland-Jones, J. M. (Eds.), Handbook of emotions. New York (NY): The Guilford Press. p. 369-392.

20. Fischer AH, Kret ME, Broekens J. Gender differences in emotion perception and self-reported emotional intelligence: A test of the emotion sensitivity hypothesis. PLoS One 2018; 13: e0190712.

21. Tran US, Hofer AA, Voracek M. Sex Differences in general knowledge: meta-analysis and new data on the contribution of school-related moderators among high-school students. PLoS One 2014; 9: e110391.

22. Serper M, Patzer RE, Curtis LM, Smith SG, O’Conor R, Baker DW et al. Health literacy, cognitive ability, and functional health status among older adults. Health Serv Res 2014; 49: 1249-67.

23. Todorovic N, Jovic-Vranes A, Djikanovic B, Pilipovic-Broceta N, Vasiljevic N, Racic M. Health literacy: Current status and challenges in the work of family doctors in Bosnia and Herzegovina. Int J Environ Res Public Health 2019; 16: 1324.

24. United Nations Development Programme. Human Development Indicators and Indices: 2018 Statistical Update Team. [Updated 2018. Accessed September 2019]. Available from: http://hdr.undp.org/sites/default/files/2018_human_ development_statistical_update.pdf

25. Durusu-Tanrı̈over M, Yıldırım HH, Demiray-Ready FN, Çakır B, Akalın HE. [Turkey health literacy study]. 1st ed. Ankara: Sağlık-Sen Publications; 2014.

26. Poureslami I, Nimmon L, Rootman I, Fitzgerald MJ. Health literacy and chronic disease management: drawing from expert knowledge to set an agenda. Health Promot Int 2017; 32: 743-754. 